\title{
Ceprotan Performing Art: A Traditional Folkart Based on Urband Legend
}

\author{
${ }^{\otimes}$ Bagus Wahyu Setyawan, Kundharu Saddhono
}

\author{
Master Program of Javanese Language Education, Postgraduate, \\ Universitas Sebelas Maret, Indonesia
}

Received: April 14, 2018. Revised: May 23, 2018. Accepted: June 10, 2018

\begin{abstract}
Traditional arts of born and develops from urban society by keeping a manifestation of its and forms are different in the regions. Ceprotan as a traditional arts from Sekar Village, Donorojo Sub-district, Pacitan Regency. Form of this research is qualitative descriptive with focused to describe and explain about Ceprotan performing art in Sekar Village, that source from the local history, that is the story of Ki Godeg and Dewi Sekar. Research object are Ceprotan performing art which held once a year, in Senin Kliwon days, in Dulqokdah month. Data collected technique using observation, noted, and content analysis. Result of research find that Ceprotan is a traditional art performed same time with Bersih Desa ceremony in Sekar Village society. Ceprotan perforiming art held once a year, only in day of Senin Kliwon, month of Dulqokdah in Lunar calendar. Ceprotan performing art performed the sendratari (dramatic dancing art) telling the story of Ki Godeg and Dewi Sekar journies with develop the Sekar Village. In the end of performing, done attraction throwing the young coconuts from some of young people from Sekar Village.
\end{abstract}

Keywords: Acculturation; Kentrung Tri Setyo Budoyo; Cultural change

How to Cite: Setyawan, B., \& Saddhono, K. (2018). The Acculturation of Kentrung "Tri Setyo Budoyo" in Dayu Village, Nglegok District, Blitar Regency: The Theoretical Study of Cultural Change. Harmonia: Journal of Arts Research And Education, 18(1), 67-73. doi:http:/ /dx.doi.org/10.15294/harmonia.v18i1.9509

\section{INTRODUCTION}

Discuss about culture and cultural wouldn't have it can be detached with people life in which the cultural was born. A difference in mindset, a social system, trust, genetic, even aspects geographical have the effect culture formation. Several factors above who made the culture of regions with each other become different. This phenomenon because culture is about human knowledge who believed to be the truth by the concerned and who are covered by it feelings and emotions, and thought other (Sutardjo, 2010). For that reason, it can be said culture and cultural is the product of thinking patterns of a society who believed to be the truth then done is constantly being in some period of time even bequeathed to their generations. The elements of culture are very much, also have very diverse product. Product of the culture that is philosophical and ideological can be seen from society activity that is based on cultural norm from their region (Priyadi \& Mulia, 2013). In Javanese society taken a belief that any man who died just their physical who died, but the spirit and their lives were still occurring. Javanese people who still life could

\footnotetext{
${ }^{\circledR}$ Corresponding author: Jl. Ir. Sutami No.36A, Jebres, Kota Surakarta, Jawa Tengah 57126

E-mail: bagusws93@gmail.com
} 
involve spirit of their fathers with certain ways (Witasari, 2015). One of them is by implementing ceremony to the ancestors. Durkheim suggests that this way is a manifestation of respect to those who are dead and must continue. To respect it cannot be significantly, but can only be achieved symbolically shaped in ritual respect to ancestral, (Hidajat, 2013). The ceremonies of reverence for ancestors is very diverse and almost in every area there are a differences. Some of them such as the slametan, bersih desa, gugur gunung, larung sesaji, umbul-donga, etc. The way and packaging of each region are different. Such is the case, bersih desa ceremony that each region is different. In Klaten, Central Java, bersih desa ceremony ordinary conducted by cleaning tombs of the ancestors continued with performances of wayang kulit in the evening. Bersih Desa ceremony in Ponorogo held in Lake of Ngebel by way of nglarung sesaji into the Lake. As for the region of Pacitan, bersih desa ceremonial packed within show a performaning art called Ceprotan

Ceprotan tradition is a ceremony already hereditary doing in there, especially in the Sekar Village, Donorojo District, Pacitan Region. Ceprotan tradition be done to keep village from the distress and dangerous thing. This tradition for villager believed containing value of trust, symbol, and magical feeling on the heritage of their culture ancestors. The society of Sekar Village, though they have received Islamic beliefs, but they just kept and uphold culture from their ancestors. It can clearly be seen on particular life, they still do some of ceremony, like slametan, burning the kemenyan (frankincense), doing sesaji (offering) in particular day regarded as the sacred day, (Wijaya \& Supriyono, 2015).

Ceprotan ceremony routine doing by the society of Sekar Village once in every year. Even this ceremony also performed in certain event, like when Birthday of Pacitan City or when there are some visitors for foreign country. This because out of a traditional art and culture in Pacitan Region who have a very important role for the community as works of religious art, for example as a means of appendages ceremony, and as complementary social life needs. In addition, traditional art is also a local culture which always maintained and of cultural values is a traditional inherited, (Wiratmoko, Djatiprambudi, \& Sulbi, 2014). Regardless have different performing show, a neat thing to be reviewed of the Ceprotan it is story which constitute the emergence of this ceremony. Head of customary said, that Ceprotan ceremony have function to memorialize the ancestors of their village, namely Ki Godeg and Dewi Sekar who have discovered Sekar Village. The wandering story of Ki Godeg and Dewi Sekar this is similar to story of Panji who are very well known in Javanese region. Panji Story derived from one of figures on the kingdom of Jenggala and Kediri, namely Raden Inu Kertapati and Galuh Candrakirana who have did many wandering as their tapa brata (sacirifice way).

Story about Panji scattered on the territory of Java Island have different versions. Panji story evolved into Pacitan area, precisely in Sekar village who believed to be a settlements builder of the Sekar Village. The story about Ki Godeg and Dewi Sekar version of Pacitan people become the other versions of Lakon Panji (story of Panji) that developing in the Javanese society. Therefore, that story is performed in ballet who telling about wandering of Ki Godeg and Dewi Sekartaji when they've created and developed Sekar Village. Ceprotan ceremony held once every year, in precisely in day of Senin Kliwon in month of Longkang (in Javanese calendar) or month of Dulqokdah in Lunar calendar. If there are no Senin Kliwon-day in month of Longkang then replaced on Sunday Kliwon (Setyawan, 2016). Determination of day and month of ceremony Ceprotan by villagers because they're believe that day considered the birth of Dewi Sekar. By commemorating the birthday of Dewi Sekar, local society in there believe she will give blessing for the people in Sekar Village. This is related to the belief of Javanese people who still believe about the power that comes from outside of the human body, that power from Almighty 
God, can also be interpreted as supernatural powers such as spirits of the ancestors like the founder of the village, and could also be considered the ancestor's spirit still provide protection to him and his descendants, (Wijaya \& Suprijono, 2015).

Reference of some description about Ceprotan performing art and background of research, can be formulated that purposes of research of this paper are to describe and explain about Ceprotan performing art as a folk-art from Sekar Village. On this tell about the form of Ceprotan staging. Furthermore, description in this paper also telling about journey of Ki Godeg and Dewi Sekar, urban legend from Desa Sekar which being a basis of Ceprotan performing art.

\section{METHOD}

The method used in this article was qualitative descriptive method using an ethnographic approach. Ethnographic study based on phenomenological view that promotes appreciation of an event. Furthermore, the phenomenology tries to depict an event in possible detail way. This previously done by Saddhono \& Rohmadi (2014a) in his research on the phenomenon of culture and tradition in Java. Ethnographic study according to Sukmadinata has particular function to describe and interpret the cultural, social group or system. Although the meaning of culture is very large, but ethnographic studies usually focused on activity, language, beliefs, rituals, and ways of living, (Mardoyo, 2008). Ethnography approach chosen because the research object in this study is Ceprotan performing arts as traditional folk-art which develop and staged in Sekar Village. Data resource collected by observation when the Ceprotan performing art are showed, in-depth interview with customary chairman and some Sekar's society. Data analysis technique using flow model of analysis and interactive analysis, step of data analysis are data reduction, presentation of data, and conclusion drawing. In this research also using triangulation to test the validity of data.

\section{RESULT AND DISCUSSION}

\section{History of Ceprotan Ceremony}

Ceprotan own derived from word "ceprot" that in Javanese language it means radiating with hard as if sprayed. The word "ceprot" taken from the sound "ceprot" when the players struck young coconuts in the ceremony. Another argument said the word "ceprot" derived of the story of the past, where the Dewi Sekar deliberately shed coconut water when she was drinking (Setyawan, 2016). It can be said Ceprotan pertaining to story of Ki Godeg and Dewi Sekar that envolve in Sekar society.

Ceprotan ceremony derived from story Panji Asmarabangun/Panji Wanengpati with Dewi Sekartaji when they was wandering until in the Donorojo area. Panji Asmarabangun and Dewi Sekartaji in their sacrifice ways often changed their name and wandering for tricked their enemies. Names like Andhe-andhe Lumut, Inu Kertapati, Joko Gudhig, and Enthit are some of the pseudonym of Panji Asmarabangun. The journey of Panji Asmarabangun is one of symbolizing that to become a King must have requires experience and sacrifice. By doing the journey, Panji could see the suffering of his people who are facing. The other source said that the journey to finding his wife (in this context is Dewi Sekartaji) was a symbol of the king who looking for his people (read: Ghozali, Fianto, \& Arwana, 2015). Related to some versions of the story about the journey of Panji, interviewees also said that when he's wandering in to region of Donorojo, Panji Asmarabangun renamed to Kyai Godeg and Dewi Sekartaji called Dewi Sekar.

Ceprotan ceremony itself comes from urband legend of Sekar Village that is a story when Kyai Godeg at that time were open agricultural land in Sekar Village. Because it was lunch, he was resting under a tree while waiting for a consignment of Dewi Sekartaji. When a rest he complained to God closed is as follows "ingsun iki among salugune titah ing donya" because the tree used to lean at that time is no name then by Kyai Godeg was given the name trees 
"glugu" which is another name of coconut trees. When looked up and said "ingsun iki ning donya ora duwe apa-apa, ora nyekel apaapa" looking toward to the fruit that then the fruit was named "klapa" in Javanese language. After he sat under a "glugu", suddenly his head downfall by young fruit and he "Aku kok krasa kelegan atiku ya bareng ketibanan woh iki" then younger coconut fruit was named "degan". Naming the objects by taking partially syllables from the name of event or term scene being regarded as having aptness called Kereta Basa (Sofwan, 2011).

The story continues when Kyai Godeg drank some of young coconut water and leaving some water for his wife. After his wife come for ushered the lunch for him, Ki Godeg give some of coconut water. However, not even to give it to his wife, suddenly appear the unpermitted sense of Ki Godeg. In the end, there is a conflict between Kyai Godeg and Dewi Sekartaji. The events that formed the basis of the Ceprotan show who use young coconut from main media, which is based on the story.

After stay for a long time in Sekar village, Kyai Godeg founded reside school and many people who want learned in there. As for the requirement for learned, Kyai Godeg should bring, cengkir, menyan, kembang setaman, pitik putih mulus, pitik ireng, mori, beras pari, beras ketan, and ayam panggang. All terms proposed by Kyai Godeg not refers to true, but rather had taken in symbolize of something or in Javanese language called "sasmita". This make some applicants make a wrong interpreted, so many of the student bringing the real requirement which reserved by Kyai Godeg. After having explained the true meaning, Kyai Godeg ask someone to gathering all of their ayam panggang (baked chicken) and divides flattened to all students. But, the divider had the trait of not fair or in Javanese language this character called "can$g a k^{\prime \prime}$. This justness activity seen in when he divide ingkung and the other food, he is taken out the part many for him. This indirectly teach about the importance of fairly character when given the mandate (Sety- awan, Saddhono, \& Rahmawati, 2017).

Aware of behavior his students is unfair, Kyai Godeg ask his wife to divide the roasted chicken with flattened. After divided shared equally to all students there are still the remaining two roast chicken, then Kyai Godeg said "Sapa wonge sing wani mlayokake panggang sisane iki mengko banjur balangana nganggo cengkir sing mbok gawa kuwi." After that, there is a student who courageous to running out the roasted chicken, then the other student pelt with the young coconut. This event as the beginning form of Ceprotan ceremony which used the young coconut already soaked

\section{Procession Ceprotan ceremony}

Ceprotan done or held in a space land, starting in the afternoon at about $06.00 \mathrm{pm}$ or could be called time of Surup. This reasons, election time of "surup" to start this ceremony because that time believed changing time for new day, whether it is from view Islamic and Javanese perception. The show begins with praying by elders in Sekar village, in this is done by Iman Tukidjo, former head of Sekar village.

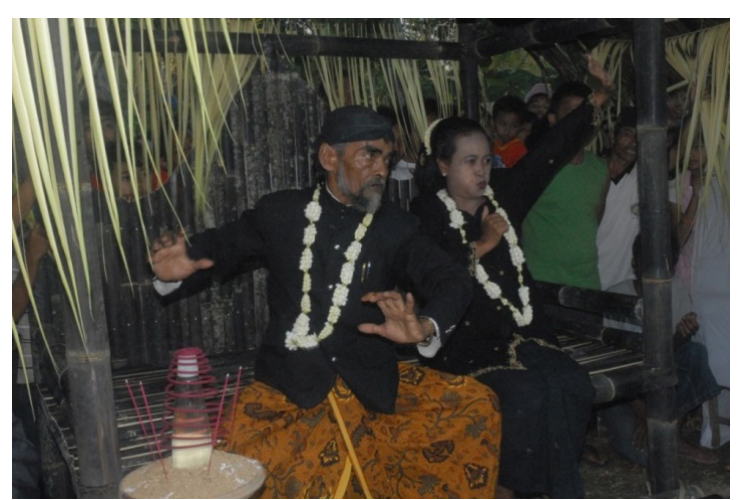

Figure 1. The Anchestor of Sekar Village and His Wife

After praying have finished, then followed by entering some people who Javanese customary dress with bringing the offering (sesaji) that are ingkung (roasted chicken), jadah ketan, beras, and some of local foods which formed like the mountain or be called "gunungan". Sesaji like kembang, dupa, and kemenyan has not changed, because sesaji believed being a sacred 
things and have doing from a while by ancestors, (Setyawan, 2016). After that followed by the entry of accompaniment who led by the head of customary bringing character of Kyai Godeg and Dewi Sekartaji, who played by his wife. This way followed by a group of young people and residents who described students walk behind him. They're display ballet performing that is confided the journey of Kyai Godeg and Dewi Sekartaji while discovered Sekar village.

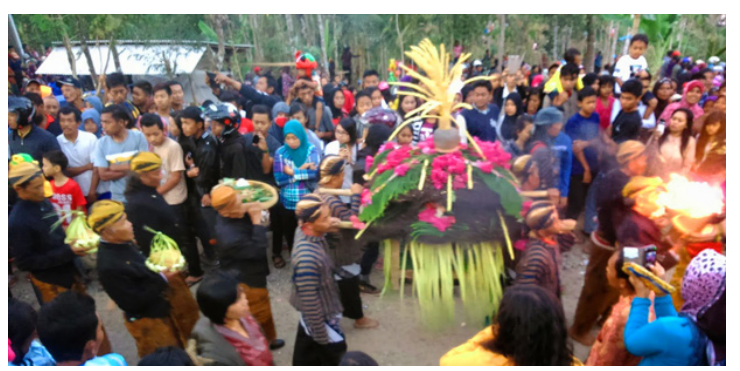

Figure 2. Entering the sesaji

The convoy of Kyai Godeg before perform a dramatic-dance first take the offering thing to gate which already decorated by janur (young coconut-leaf). Around the place of Ceprotan ceremony also have been prepared some coconut which already soaked before and placed in a basket. After dramatic-dance have about Kyai Godeg and Dewi Sekartaji have been done, young people as students of Kyai Godeg divide themselves into two groups. According to explanation before, there is someone who running out the ingkung or commonly called "pitik cangakan" then the carrier of ingkung pelted with the coconuts by the other. So on each other throw young coconuts between one groups to the enemies group until the coconut used up. They all believe in that whoever affected by splashing water of coconut can get blessing (Saddhono \& Supeni, 2014b). After all process just finished jointed with the dance together and reading invocations by elders of Sekar village. A ceremonial procession Ceprotan closed by the distribution of the offerings such as roast chicken (ingkung), jadah ketan, rice, and other local foods to the citizens who is in the area of ceprotan per- formances.

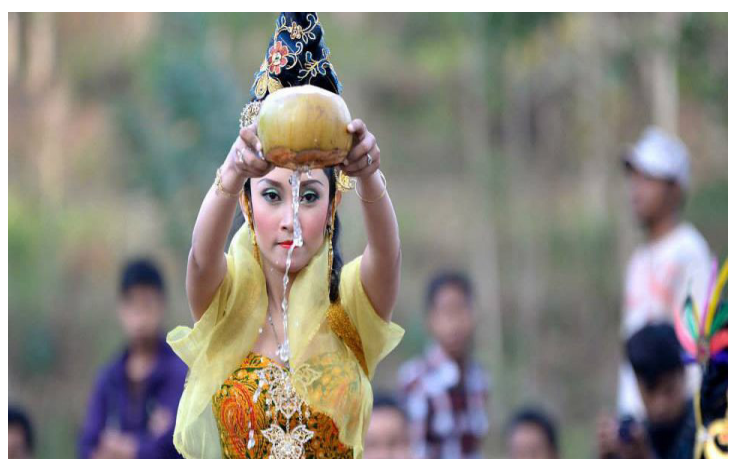

Figure 3. Dewi Sekartaji bringing a young coconut

\section{Ceprotan as Traditional Ceremonies Sourced from Urban Legend}

Like has been discussed before, that Ceprotan is traditional ceremonies sourced of story of Panji. Panji story already known in the Javanese society, especially in East Java. As stated by Raffles, Panji Story started to be known since the days of Majapahit era who takes background the kingdom of Kediri and Jenggala. The main figure is Panji Asmarabangun and Dewi Sekartaji. In the progress of Panji Story spread to various regions in Indonesia and even until to Southeast Asia region by displaying variant different, (2008).

Story of Panji is a local story which have been re-interpretation (disanggit) into various version, for examples story Timun Emas, Keong Emas, Cinde Laras, Kethek Ogleng, Enthit, Klething Kuning, Jaka Kembang Kuning, and the others, (Bagyo, 2005). Some of Panji Story developed in many regions and still alive to now for being an icon of that area. Story of Kethek Ogleng derived from Wonogiri, Central Java is also sourced from Story of Panji. The name Kethek Ogleng take from one figure in Panji Story who tell about son of the Jenggala's King named Panji Gunung Sari. At the time of his father are told to look for his broter's wife, Dewi Sekartaji who leave the Kingdom. To ease in finding Dewi Sekartaji, Panji Gunungsari using "Kethek Ogleng" as his pseudonym. After looking for a long time, finally he met with Sekartaji (disguised as Rara Tompe) in Dhada- 
pan village on Mbok Randha Dhadapan's house, (Warto, 2014).

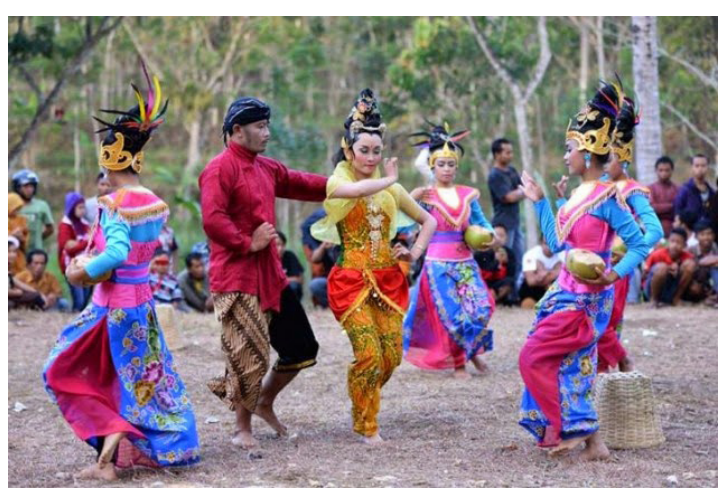

Figure 4. The dramatic dance art telling the Journey of Ki Godeg and Dewi Sekar

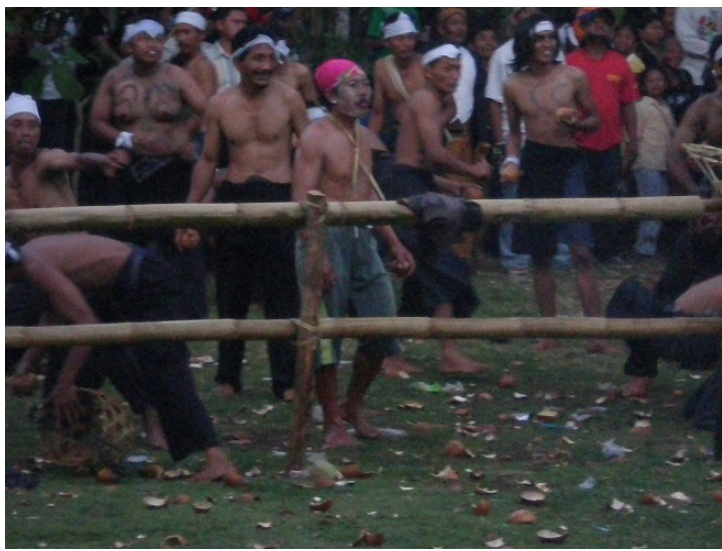

Figure 5. Some of people throwing the young coconut

Another version of Panji Story who became a legend in Pacitan, specifically in the Sekar Village, is story about Kyai Godeg and Dewi Sekar. Story about journey of the married couple to lime mountainous areas and still quiet population. After developed the village and set up hermitage, slowly the area being rural crowded. Then, rural area given names Sekar Village, taken from one of the founder village, namely Dewi Sekar. Until now, villagers of Sekar village to respecting the honor of their ancestor and they're held Ceprotan ceremony which is celebrated once time every year. The story Kyai Godeg and Dewi Sekartaji that flourished in Sekar Village must be unchanged from the ancestors until now. Parents are telling the same story to their children, to keep ancestral tradition. This is because inheritance tradition an ances- tor as one important thing which showing authentically identity of culture in certain society. Authentically of cultural is important to become identity of people who have and develop it (Ambarwangi, 2014). For that reason, packaging forms as well as Ceprotan ceremonies unchanged and remain the same from time to time.

\section{CONCLUSION}

Bersih desa ceremony performed by different in every region. In Pacitan region there is bersih desa ceremonies which packed with arts performance called with the term "Ceprotan". Ceprotan ceremony done once time every year, in the day of Senin Kliwon on the month of Longkang (in Javanese calendar) to commemorate the birth of Dewi Sekar, one of the ancestral in Sekar Village. In Ceprotan ceremony also means re-actualizing of local history in that village. This can be seen from depiction the journey of Kyai Godeg and Dewi Sekar when discovered Sekar village. Story of Kyai Godeg and Dewi is one kind of Panji Story. Panji Story dominant tells about the story of wandering Panji Asmarabangun and Dewi Sekartaji. It can be said story of Kyai Godeg and Dewi Sekar that develops in the Sekar village can add the diversity version of Panji story. Until now the story of Kyai godeg and Dewi Sekartaji still believed by Sekar society as well as not changed in the least the story. It was because the society of Sekar Village these as cultural heritage of their ancestor. Ceprotan ceremony contain value of the manners that can be seen from the tools like cengkir, kembang, ingkung, jenang, and so forth. All of them containing a very deep meaning. With progress in Ceprotan ceremonies become cultural event in Pacitan who often shown in certain and important event, like birthday of Pacitan and in treating when state guests has come.

\section{REFERENCES}

Ambarwangi, S., \& Suharto, S. (2014). Reog as Means of Students'appreciation 
and Creation In Arts and Culture Based on The Local Wisdom. Harmonia: Journal of Arts Research And Education, 14(1), 37-45.

Bagyo, S. (2005). Wayang Beber Wonosari. Wonogiri: Bina Citra Media.

Ghozali, M. A., Fianto, A. Y. A., \& Riyanto, D. Y. (2015). Penciptaan Buku Ilustrasi Tari Topeng Panji Malangan Untuk Mempopulerkan Budaya Tradisional Kota Malang Kepada Remaja. Jurnal ArtNouveau, 4(2), 102111.

Hidajat, R. (2013). Transformasi Simbolis Empat Tokoh Sentral Seni Pertunjukan Wayang Topeng Malang di Jawa Timur. MUDRA, 28(1), 1-9.

Mardoyo. (2008). Pengendalian Mutu Kinerja dan Kompetensi, Jurnal Penelitian, 9(1), 1-9.

Priyadi, S., \& Mulia, D. S. (2013). UnsurUnsur Kearifan Lokal Masyarakat Pesisir Cilacap. Paramita: Historical Studies Journal, 23(2), 53-65.

Raffles, T. S. (2008). History of Java. Yogyakarta: Narasi.

Saddhono, K., \& Rohmadi, M. (2014). A sociolinguistics study on the use of the Javanese language in the learning process in primary schools in Surakarta, Central Java, Indonesia. International Education Studies, 7(6), 25-31.

Saddhono, K., \& Supeni, S. (2014). The Role of Dutch Colonialism in the Political Life of Mataram Dynasty: A Case Study of the Manuscript of Babad Tanah Jawi. Asian Social Science, 10(15), 1-9.
Setyawan, B. W. (2016). Eksplorasi Nilai Sosial dan Kearifan Lokal dalam Pertunjukan Kesenian Ceprotan di Desa Sekar, Kecamatan Donorojo, Kabupaten Pacitan. spread on Cultural Nation Conference "Membangun Budi Pekerti melalui Kesenian Daerah" held by UPKD FKIP UNS".

Setyawan, B. W., Saddhono, K., \& Rakhmawati, A. (2017). Sociological Aspects and Local Specificity in the Classical Ketoprak Script of Surakarta Style. Journal of Language and Literature, 17(2), 144-151.

Sofwan. (2011). Kawruh Aruming Basa. Surakarta: Widya Duta Grafika.

Sutardjo, I. (2010). Kajian Budaya Jawa. Surakarta: FSSR UNS.

Warto, W. (2014). Revitalisasi Kesenian Kethek Ogleng Untuk Mendukung Pengembangan Pariwisata Di Kabupaten Wonogiri. Paramita: Historical Studies Journal, 24(1), 47-62.

Wijaya, F. A. \& Suprijono, A. (2015). Perkembangan Tradisi Ceprotan Di Desa Sekar Kecamatan Donorojo Kabupaten Pacitan 1981-2013. Avatara, 3(3), 469-479.

Wiratmoko, C., Djatiprambudi, D., \& Sulbi. (2014). Suwardi: Tokoh Pengembang Wayang Beberdi Pacitan. Jurnal Seni Rupa, 2(3), 98-105.

Witasari, N. (2016). Astha Brata Dan Pranata Mangsa: Alam Dan Relasi Kuasa Dalam Konteks Agraria Di Jawa. Paramita: Historical Studies Journal, 25(2), 225-237. 